Paweł Pieniążek

\title{
Współczesność i historia w metafizyce E. Levinasa
}

Począwszy od XIX w., a konkretnie od Hegla, współczesność staje się powoli problemem filozoficznym, co znaczy, że nie jest już ujmowana jako zewnętrzna wobec samego aktu filozofowania sytuacja (ekonomiczno-społeczna, kulturowa etc.), której neutralność względem tegoż aktu zostaje co najwyżej zniesiona w retrospektywnym spojrzeniu określającym związek między naiwną w swej samowiedzy myślą a jej wielorakimi uwarunkowaniami, lecz że zostaje objęta samym ruchem filozoficznej refleksji, stając się uprzywilejowanym obiektem jej inicjalnego gestu, a zarazem argumentem par excellence filozoficznym.

Przesłanką nadania filozoficznego statusu współczesności jest przeświadczenie, że za przebiegiem faktycznej historii kryją się nieredukowalne do niej - niedające się ująć w jej kategoriach - pierwotne sensogenne gesty, znaczące formacje sensu, nadające sens rozproszonej wielości kulturowych zdarzeń. Jako manifestacja owych znaczeniotwórczych projektów współczesność byłaby doświadczana - negatywnie - w perspektywie rewindykującej autentyczność istnienia ludzkiego prawdy uniwersalnej. Jawiłaby się tedy jako radykalne, posunięte do granic możliwości, zaprzeczenie owej uniwersalności, jej brutalny - przywołujący ją niczym lustrzane odbicie - antysens, który w swej złowieszczej spektakularności czyniłby z nostalgicznego odwołania się do uniwersalności nieodparty i palący wymóg poszukującej w odwróconym świecie ratunku egzystencji ludzkiej. 
W takiej też perspektywie należy widzieć myśl Levinasa: odniesienie do współczesności i historii ożywia cały jego metafizyczny dyskurs, czyniąc go esencjalnie współczesnym. Ta aktualność nie ogranicza się zatem do banalnej prawdy, że Levinas żyje w dzisiejszych czasach, że jego myśl jest zrozumiała wyłącznie przez odniesienie do filozoficznej współczesności, czyli do myślowego horyzontu epoki, jej problemów, pojęciowych zasobów etc., lecz bierze się właśnie z faktu, że współczesność staje się jej zasadniczym problemem, gdyż dopiero doświadczenie jej otwiera dostęp - apokaliptyczny - do królestwa uniwersalności.

Otóż dla Levinasa pierwszymi faktami ludzkiego doświadczenia świata nie są bynajmniej rzekomo neutralne fakty empiryczne, lecz nieprzekraczalne, czyli odnoszące się do samej esencji istnienia ludzkiego, fakty historycznej współczesności XX w. - wojny światowe, totalitaryzm, ludobójstwo, Holocaust i Auschwitz, stanowiący ,paradygmat tego nieuzasadnionego cierpienia ludzkiego, w którym zło przejawia się w swym diabolicznym horrorze" (ENE, s. 111). Zło historii jest złem czystym i jawnym, złem, dla którego nie można już znaleźć jakiegokolwiek neutralizującego je alibi, czy to w postaci teodycei, czy historiodycei. Jeśli usprawiedliwienie zła stanowiło jeden z zasadniczych ,składników samowiedzy ludzkości europejskiej”, to dziś nie jest już możliwa „równowaga między teodyceą explicite i implicite myśli zachodniej a formami, jakie cierpienie i związane $\mathrm{z}$ nim zło przyjmują $\mathrm{w}$ trakcie rozwoju tego stulecia [...]” (ENE, s. 114). Toteż radykalne zło XX w. stanowi dla Levinasa nieodparty dowód na nieistnienie Boga religii objawionych, który „milczał w Auschwitz”: „Czyż powiedzenie Nietzschego o śmierci Boga nie uzyskuje w obozach koncentracyjnych znaczenia quasi-empirycznego" (ENE, s. 115).

Stanowiąc dla Levinasa czystą naoczność, powyższe zdarzenia dwudziestowiecznej współczesności ukazują w swej złowieszczej ewidencji, iż niszcząca substancję człowieczeństwa przemoc staje się uniwersalną zasadą istnienia ludzkiego. Do nich też musi się odnieść - zrodzona z tego etycznego distinguo - myśl, jeśli chce stać się filozofią o aspiracjach uniwersalnych, angażujących przeto pytania o elementarny sens istnienia ludzkiego, a taka tylko - zdaniem Levinasa - może pretendować do miana (pytającej przecież o miejsce człowieka na ziemi) filozofii. Ów patos zagrożenia określa bez reszty dyskurs Levinasa, granice jego samowiedzy i etyczny walor inaugurującego filozofię zdziwienia. 
Jednakże w przekonaniu Levinasa za apokaliptycznymi faktami współczesności kryje się władza całej historii. Levinasowskie doświadczenie historii to doświadczenie panującej nad jednostkami i bez reszty podporządkowującej je sobie bezosobowej mocy. Uwięzione w swej przypadkowej - zrelatywizowanej do hic et nunc faktyczności historii, poddającej je oddziaływaniu anonimowych sił - partykularności jednostki nie są kreatorami historii, lecz jej bezsilnymi i niemymi ofiarami, podlegają przebiegającym ponad nimi ruchom historii, uczestniczą w niej jedynie przez swoje zaangażowanie masowe, zagubione, nie rozumieją wymykających się im spod kontroli żywiołowych procesów, ich mielących masy ludzkie mechanizmów. Historia wywłaszcza jednostki z ich osobowej istoty (wolność, odpowiedzialność), sprowadza ich byt do bytu rzeczy. Owo radykalne depersonalizujące ubezwłasnowolnienie jednostek w „niezrozumiałym zazębieniu porządku uniwersalnego” „,nie pozostawia nikogo na marginesie życia", czyni jednostki, jak powiada Levinas w swoim wczesnym tekście, „mobilizowalnymi” (DE, s. 375).

Współczesność staje się zatem dla Levinasa problemem samej historii, problemem jej kryzysu i znaczenia dla istnienia ludzkiego. Toteż autor Totalité et Infini nie przedstawia jakiejś nowej postheglowskiej czy postmarksowskiej refleksji nad historia, refleksji czyniącej z historii wyróżniony przedmiot filozofii, czyli przekształcającej się w filozofię samą. Jeśli bowiem powiada się, że wraz z Heglem i Marksem filozofia odkryła nowy „kontynent” i jeśli w konsekwencji uznaje się, że jedynie ona stanowi układ odniesienia dla rozumienia człowieka, czyli staje się źródłem i nośnikiem sensu, a zgodność z jej uniwersalnymi prawami miarą sensowności i racjonalności jednostek, to Levinas z cała gwałtownością poglądów odrzuca: oznajmia właśnie kres i ruinę mitu historii jako progresywnie rozwijającej się i aktualizującej założony w niej od początku sens całości racjonalnej, z której ,,jednostki czerpią sens (niewidzialny poza tą totalnością), w której odnajdują sens własnych narodzin i śmierci" (TI, s. X). Konsekwentnie pomyślany finalistyczny i optymistyczny historyzm - zgodnie z którym historia staje się jedynym, ontologicznym horyzontem doświadczenia świata, a jednostki jedynie przez sensowny porządek historii stają się rozumne i uczestniczą $\mathrm{w}$ świecie rozumnym i sensownym - nie pozwala ugruntować współkonstytuującego osobową esencję człowieka jednostkowego charakteru istnienia ludzkiego: podporządkowuje bowiem jednostki, w imię wyższych racji, państwom, 
narodom, klasom; uznaje zło za konieczny składnik realizującego się w historii rozumu, sankcjonuje przemoc jako nieusuwalny środek realizacji celów historii.

Swój najwyższy wyraz przemoc historii znajduje w osądzie historii: za Heglem Levinas mówi „Die Weltgeschichte ist die Weltgericht”. Jednostki uzyskują „obiektywne znaczenie” przez odniesienie do uniwersum historii, są zatem osądzane na podstawie „,całości swoich dzieł”, wpisujących je w byt historii, tworzących jej rozumną rzeczywistość. Osąd jest zatem obiektywny, gdy jednostki są osądzane na podstawie ostatecznych rezultatów swych działań mających stanowić jedyną miarę oceny ich życia, które poza historią dzieł byłoby w swej wewnętrzności pustką ,„czysto subiektywnych zdarzeń ginących w piaskach wewnętrzności, z której kpi rozumna rzeczywistość" (TI, s. 227). Osąd ów spełnia się zatem wraz ze śmiercią jednostki, jest zawsze pośmiertny - zaoczny. Przed sądem historii jednostki występują ,jedynie w trzeciej osobie", są opowiadane w „mowie zależnej”, reprezentowane przez totalizujące ich życie w kategoriach zdarzeń zewnętrznych „,biografie”, które tworzą „,historię historiografów”: „Historiografia opowiada o sposobie, w jaki ci, którzy przeżyli, przyswoili sobie dzieło wól zmarłych" (TI, s. 204); jest tworzona przez zwycięzców. Przed sądem historii jednostka zostaje pozbawiona prawa obrony, nie może usprawiedliwić swoich działań przez ukazanie ich racji i motywów stanowiących dla osądzających niebyt. Osąd jednostek jest przeprowadzany w perspektywie ostatecznego celu historii poświęcającego każdą chwilę ,na rzecz przyszłości przywoływanej dla ujawnienia sensu obiektywnego. Liczy się bowiem sens ostateczny, tylko ostatni akt przemienia byty w nie same" (TI, s. X). Miarą uzyskania przez jednostkę znaczenia uniwersalnego jest zgodność jej woli subiektywnej z wolą obiektywna, czyniące ją rozumną uczestnictwo w instytucjonalnym porządku historii pozwala ostatecznie usprawiedliwić arbitralną wolność i przezwyciężyć śmierć. Jednakże ceną usprawiedliwienia, jakiego jednostce dostarcza uniwersalność jej istnienia historycznego, jest negacja jej jako jednostki: „osąd jako osąd historii zabija wolę jako wolę” (TI, s. 218).

W przekonaniu Levinasa historyzm jako racjonalistyczny projekt historii, stając się aktywnym składnikiem jej opisywanego przez siebie ruchu, doprowadził w imię rewindykowanych przez siebie wartości zło historii do jego wymiarów apokaliptycznych. W ten sposób pada 
ofiara „dialektyki oświecenia” (Levinas podtrzymuje tu tezę Adorna i Horkheimera): wszystko to, co umożliwiło uwolnienie człowieka od bezpośrednich związków z bytem (naturą), ukonstytuowanie się go jako bytu wolnego, przekształca się w miarę rozwoju historii we własne przeciwieństwo, prowadzi do wywłaszczenia człowieka jako rozumnego podmiotu historii, do ,inwersji rozumnych projektów”, przez które miał on poddać racjonalnej kontroli żywiołowy ruch historii. Dialektykę oświecenia określa zatem skrajna rozbieżność między ucieleśniającymi w ruchu historii humanistyczne ideały projektami emancypacyjnymi a ich rezultatami. Wyrosłe z rozpoznania alienacji człowieka w świecie projekty prowadzą do przekształcenia się dezalienacyjnych ideałów w uświęcające przemoc brutalne ideologie, do zdwojenia alienacji i nadania jej uniwersalnego charakteru: „Dziejowa trwoga jest głęboka. Pochodzi z doświadczenia rewolucji pogrążających się w totalitarnej represji i przemocy, podających się za rewolucje. Otóż w nich alienuje się sama dezalienacja” (HAH, s. 87).

Spektakularnym przypadkiem dialektyki oświecenia jest dla Levinasa marksizm nawiązujący do określającej duchowość Europy tradycji judeochrześcijańskiej. W warstwie filozoficznej marksizm, przez swój ścisły determinizm, zaprzecza co prawda stanowiącej wyznacznik tej tradycji ,duchowej wolności, która oznacza dla cywilizacji europejskiej koncepcję przeznaczenia człowieka. Jest ona poczuciem wolności absolutnej człowieka wobec świata [...]" (QRPH, s. 155). Jednakże marksizm nie neguje do końca wolności, przywraca ją bowiem jednostce wówczas, gdy rozpoznaje alienacyjny charakter rzeczywistości społecznej; wraz z tym rozpoznaniem „uwalnia się od fatalizmu”. Poprzez „etyczny bunt” przeciw uniwersalnej opresji marksizm nawiązuje - co stanowi o jego „szlachectwie” - do tradycji judeochrześcijańskiej; w ,stadium młodzieńczym” marksizm cechowała ,wiara, heroizm, czystość [...], przywiązanie w teorii do wielkich idei humanistycznych [...]" (TW, s. 217). Niezależnie od waloryzacji deterministyczno-materialistycznej koncepcji człowieka, relatywizacji wartości i radykalizacji pojęcia ideologii, marksizm ponosi porażkę - nade wszystko - w sferze historycznej praxis, wówczas, gdy w imię wolności i sprawiedliwości prowadzi do aktywnie negującego te wartości systemu totalitarnego: „Dla mnie jednym z największych rozczarowań historii było to, że taki ruch jak ten wydał z siebie stalinizm. To już koniec" (ENE, s. 139). 
Zamykając jednostki w totalizującej ich byt immanencji historii, dialektyka oświecenia prowadzi do zniesienia jednostkowości człowieka i jego osobowej struktury. Z tego właśnie powodu Levinas nie zwraca się ku tradycyjnej metafizyce rozważającej człowieka poza jego empiryczno-historycznym stawaniem się. Wyrosła $\mathrm{z}$ greckiego racjonalizmu metafizyka ujmuje jednostki w ich ponadempirycznych, idealnych - znoszących ich partykularność - esencjach, jako składnik intelligibilnej struktury zamkniętego w sobie, samowystarczalnego kosmosu. Jednostka znaczy, ma wartość, jedynie przez swoje depersonalizujące, uniwersalizujące jej byt uczestnictwo w intelligibilnej immanencji całości bytu. Jeśli zatem Levinas kwestionuje wartość tradycyjnej metafizyki dla rozumienia człowieka, to nie dlatego, że brutalna „codzienna historia świata” ukazuje bezużyteczność i nazbyt idealistyczny charakter metafizycznej wizji świata, lecz właśnie dlatego, że w wizji tej dostrzega pewien fundamentalny, leżący u podstaw kultury Zachodu projekt świata, którego istotę stanowi właśnie rozumienie człowieka przez odniesienie go do przekraczającej go i fundującej jego istnienie całości bytu. W tej optyce historyzm, rewindykujący uniwersalną rozumność historii, stanowiłby jedynie przedłużenie metafizycznego projektu świata. Historia XX w. wraz z jej radykalnym złem stanowi dla Levinasa właśnie spełnienie tego projektu, będące zarazem spełnieniem się samego bytu, którego ,jakby czystym doświadczeniem staje się wojna” (TI, s. IX): Levinas ujmuje bowiem historię jako intelligibilne rozwinięcie przedludzkiego bytu - oto racja, dla której współczesność uzyskuje w oczach Levinasa sens filozoficzny, stając się argumentem w dyskursie o prawdzie człowieka.

Otóż Levinas gruntuje historię w ontologicznej strukturze człowieka - nazwanej Tym-samym - na mocy której, odrywając się od przedludzkiego i przedintelligibilnego bytu anonimowego il y a-czyste istnienie, bezosobowe trwanie - konstytuuje się on jako ja autonomiczne i tożsame z sobą. Tożsamość ta nie stanowi substancjalnego bezruchu, lecz fundamentalny sposób bycia-w-świecie, aktywne odnoszenie się człowieka do siebie przez świat. Kolejne fazy konstytucji podmiotu tworzą momenty dialektyki, na mocy której ja zależne od bytu przedludzkiego przekształca go w intelligibilny moment własnej tożsamości. Na poziomie zmysłowym tej konstytucji ja tworzy swą zalążkową, czysto subiektywną tożsamość przez rozkoszowanie się amorficznym światem żywiołów (czyste asubstancjalne jakości zmysłowe). Na poziomie ekonomicznym zależne od świata 
żywiołów ja zmysłowe zabezpiecza zagrożone (niezaspokojenie potrzeb otwiera depersonalizujący byt il y a, który stanowi „mroczną” stronę żywiołów) rozkoszowanie się naturą poprzez odroczenie go i przekształcenie bezkształtnych żywiołów w dysponowalny przedmiot pracy i świadomości poznawczej i w ten sposób konstytuuje intelligibilny porządek świata. Ja odrywa się od bytu i przekształca go w obiektywny świat, w którym rozpoznaje się i odnajduje własną tożsamość znoszącą jego odmienność, wpisującą go zatem we własną monadyczną immanencję. Świat - świat obiektywnych dzieł pracy i świadomości - stanowi ontologiczną tkankę historii konstytuującej się wówczas, gdy monadyczne i egoistyczne indywidua wchodzą ze sobą we wzajemne relacje, stosując do nich miarę swego - ontologicznego - egoizmu, czyli usiłując wzajemnie znieść swą odmienność. Zniesienie tego konfliktu (jego modelem jest dla Levinasa Hobbesowski stan natury) dokonuje się przez ustanowienie ponadjednostkowej, racjonalnej całości państwa - za cenę ograniczenia wolności jednostek. Historia - właśnie jako historia państwa - stanowi rozwijającą się w czasie, złożoną z dzieł całość obiektywnego wymiaru istnienia człowieka w świecie. W tej obiektywnej ekspresji człowieka w świecie Levinas upatruje źródło jego naturalnej alienacji: dzieło jest produktem przekształcającej świat aktywności ludzkiej, takiej jednak, iż ,produkcja potwierdza autora dzieła pod nieobecność autora" (TI, s. 203). Dzieło odrywa się bowiem od swego twórcy, ,wchodzi w kontekst całkowicie odmienny od tego, który je zrodził", przyjmuje inne - znaczenie aniżeli to nadane mu przez jego twórcę.

Ta naturalna, właściwa historii alienacja dzieła przekształca się w uniwersalną alienację człowieka i historii, odkąd w świecie własnych dzieł człowiek ulega pokusie interpretowania siebie i innych w kategoriach rzeczowych i ,krzepnie w osobistość interpretowaną na podstawie swego dzieła". Usiłując wyrazić się w świecie swoich dzieł, uznając zatem, iż wyczerpuje swoją , istotę" w obiektywnym - historycznym - wymiarze swojego istnienia, człowiek - podmiot historii - rezygnuje z własnej „wewnętrzności”. Sumująca całość zjawiskowego wymiaru człowieka historia przekształca się $\mathrm{w}$ historię uniwersalną, podporządkowuje sobie bez reszty jednostki, którym jawi się jako sam byt - „byt w sobie" - totalizująca całość doświadczenia ludzkiego rzeczywistość ostateczna. Historia uniwersalna zakreśla tym samym ostateczny wymiar uprzedmiotowienia człowieka: sukcesywnie postępująca totalizacja bytu przez historię znosi w jej bezosobowej immanencji wszelką pozahisto- 
ryczną odmienność - zarówno wewnętrzność instaurującego porządek historii człowieka, jak i odmienność, inność bytu i Drugiego.

$\mathrm{W}$ ten sposób spełnia się leżąca u podstaw dialektyki oświecenia wewnętrzna dialektyka istnienia-w-świecie, na mocy której to, co monadycznej, wciagającej świat w orbitę własnej immanencji, jednostce miało przynieść zabezpieczenie przed wolnością innych i usprawiedliwienie wolności własnej, a mianowicie historiogenne zapośredniczenie tej wolności $\mathrm{w}$ racjonalnym porządku instytucji społeczno-politycznych, przekształca się we własne przeciwieństwo, prowadząc do zniesienia wolności jednostki w totalności historii. Opisana przez Levinasa dialektyka identyfikacji człowieka w świecie, prowadząca od ja zmysłowego identyfikującego się od wewnątrz do ja identyfikującego się przez porządek świata obiektywnego, stanowi ostatecznie odwrócenie w porządku historii logiki separacji, która wiedzie od ja zależnego od natury do ja oddzielonego: budząca trwogę, depersonalizująca immanencja bytu przedludzkiego odtwarza się na poziomie bycia-w-świecie ${ }^{1}$ pod postacią znoszącej byt osobowy immanencji rozumu historycznego, która przynosi ,cierpienie [...]; alienuje człowieka przez samą uniwersalność, która od zarania naszej cywilizacji powinna zagwarantować - człowiekowi człowieczeństwo" (NP, s. 133).

Historia realna jest zatem urzeczywistniającą się pod znakiem Tego-samego historią uniwersalną: ,totalitaryzm polityczny opiera się na totalitaryzmie ontologicznym" (TW, s. 219); w tej perspektywie wiek XX - ,wiek wojen światowych i obozów koncentracyjnych, totalitaryzmu i ludobójstwa, terroryzmu i brania zakładników, rozumu przekształcającego się w stalinizm" (TW, s. 219) - jawi się jako zwieńczenie totalitarnej historii Tego-samego.

Wydaje się jednakże, że dialektyka oświecenia nie wyczerpuje apokalipsy historii Zachodu. W analizach Levinasa da się odnaleźć jej jeszcze głębszy wymiar, jeśli bowiem dialektyce oświecenia poddaje on totalitaryzm komunistyczny, to nie czyni tego w odniesieniu do faszystowskiego;

1 Jeśli Levinas opisuje kryzys historii w kategoriach bytu anonimowego, to w gruncie rzeczy właśnie opanowana przez przemoc historia ,naszego wieku” dostarcza mu modelu dla opisu tegoż bytu; w pierwszej swojej samodzielnej pracy, w De l'evasion z 1936, w której pojawia się problem pierwotnej relacji człowieka z istnieniem anonimowym, Levinas, analizując istnienie ludzkie uwikłane w depersonalizujący je byt, mówi o „bycie ja, które wojna i powojnie pozwoliły nam poznać" (DE, s. 375). 
temu nadaje niejako inny status ontologiczny. Otóż faszyzm nie wyrasta z rewindykujących wolność ,wielkich ideałów humanistycznych” cywilizacji judeochrześcijańskiej, lecz ,kwestionuje same zasady (tej) cywilizacji”. Właściwa dla ukrytej za „nędzną frazeologią” „filozofii hitleryzmu” „,nowa koncepcja człowieka” uznaje prymat sytuacji nad wolnością w sytuacji, rozumianej już nie jako ograniczenie wolności, lecz jako ,podstawa samego bytu" ludzkiego, która konkretyzuje się w cielesności; tej zaś nie ujmuje się jako krępującej ,swobodny pęd ducha” materii, lecz jako pierwotny wymiar jego istnienia: człowieka nie określa wolność, lecz nierozerwalna więź z ciałem stanowiącym nośnik ,tajemniczego głosu krwi, wezwania płynącego z dziedzictwa i przeszłości” (QRPH, s. 157). $\mathrm{W}$ tej waloryzującej rasowy charakter ciała koncepcji społeczeństwo jest wspólnotą krwi, nie zaś, jak w koncepcji liberalnej, wytworem ,zgody wolnych wól". Pograżonemu w kryzysie światu liberalno-demokratycznemu, w którym zostaje zerwana więź między stającą się celem samym w sobie wolnością a prawdą i który nie angażuje się w „tworzenie wartości duchowych", „germański ideał człowieka jawi się jako obietnica szczerości i autentyczności". Wolność nie określa już dystansu wobec idei, nie mediatyzuje prawdy - w czym Levinas dostrzega niezbywalną wartość świata zachodniego - lecz zostaje zakorzeniona. Nie mniej jednak ,ten typ prawdy” "nie może zrezygnować z formalnej natury prawdy i przestać być uniwersalnym” - tym, co „uzgadnia uniwersalność z rasizmem” może być tylko przemoc. Na mocy tej „,uniwersalizacji przemocy i podboju” „cywilizacja judeochrześcijańska zostaje zakwestionowana przez aroganckie barbarzyństwo zainstalowane w sercu Europy" (AM, s. 142). Barbarzyństwo nie ma tu wszakże sensu prostego epitetu moralnego, Levinas łączy je bowiem z poganizmem oznaczającym preontologiczną i pretechniczną postawę wobec bytu - bezpośrednią, znoszącą osobową strukturę człowieka i poddającą go bezpośrednim wpływom prerefleksyjną więź z bytem, depersonalizującą podległość jego bezosobowym mocom². Poganizm jest dla Levinasa mitologiczną figurą istnienia w łonie przedludzkiego bytu il y $a$.

${ }^{2}$ Właśnie wskazanie pogańskiego wymiaru filozofii Heideggera pozwoliło Levinasowi pokazać jej bliskość z faszyzmem i wyjaśnić zaangażowanie niemieckiego filozofa po stronie nazizmu: w myśli Heideggera, jak sądzi Levinas, wyraża się gloryfikacja mistycznego i prerefleksyjnego, znoszącego techniczną alienację człowieka zakorzenienia, czyli bezpośredniej więzi z Ziemią, Miejscem. 
Teraz też staje się jasne, dlaczego Levinas nie wpisuje nazizmu w stymulującą bieg historii dialektykę oświecenia: zdzierając ostatecznie z historii pozór racjonalności i uniwersalności, obnażając bankructwo stojących za nią wartości, jawi się on Levinasowi jako realność zewnętrzna wobec jej dialektyzowanego ruchu, jako miejsce irrupcji $\mathrm{w}$ historii Tego-samego poganizmu, a wraz $\mathrm{z}$ nim anonimowego il y $a$, stanowiącego w ten sposób ukryte, mroczne dno historii. To, co stanowiło jednostkową, ontologiczną możliwość ludzkiego bytu stawałoby się możliwością samej historii, która - przekształcając się w ten sposób we własne przeciwieństwo - traciłaby swą antropogenną odrębność i prowadziła do rozpadu stotalizowanego przez siebie bytu usensownionego i uczłowieczonego. Jeśli w uruchomionej przez dialektykę oświecenia historii przemoc stanowiła zasadę urzeczywistnienia humanistycznych ideałów, to w poganizmie nazistowskim staje się ona kwestionującą same te ideały, wywłaszczającą człowieka z istnienia osobowego zasadą bytu: toteż Levinas może powiedzieć, iż tym, co zostaje zakwestionowane we współczesnym poganizmie, nie jest już jakiś składnik „kultury chrześcijańskiej i liberalnej”, „taki czy inny dogmat demokracji parlamentarnej”, lecz „samo człowieczeństwo człowieka” (QRPH, s. 159) $)^{3}$.

Historia Zachodu, wówczas gdy przez dialektykę oświecenia konstytuuje się jako bezosobowa całość oraz gdy odtwarza i aktualizuje na gruncie bycia-w-świecie istnienie anonimowe il y a, stanowi dla Levinasa totalitarny aspekt historii Tego-samego - alienacji wolności i niepowtarzalności człowieka.

Owa alienacja wolności zdaje się posiadać jeszcze inne oblicze, a mianowicie indywidualistycznej rewindykacji wolności. Jeśli w totalistycznym wymiarze historii Tego-samego wolność, rozumiana jako uwalnianie się od ,determinizmów rzeczywistości”, prowadziła do zmediatyzowanego przemocą ukonstytuowania się totalności wspólnoty, to w wymiarze indywidualistycznym, wymiarze „ostatecznych konsekwencji,

3 Łatwo teraz zrozumieć, dlaczego w Holocauście Levinas dostrzega rzeczywistą miarę kryzysu człowieka: istnieniu pogańskiemu reprezentowanemu przez faszyzm Levinas przeciwstawia judaizm jako historyczną, ,ilustrację" człowieczeństwa i w tej perspektywie może mówić o apokaliptycznym wymiarze historii, kryzysie historii jako kryzysie samego człowieczeństwa. 
jakie pociaga za sobą idea wolności”, podlega ona radykalnej autonomizacji, prowadząc do sukcesywnego ,wyzwalania pragnienia”:

[...] pojęcie wolności doznaje ,postępu” w następujący sposób. Od wyzwolenia ekonomicznego do wolności seksualnej, do edukacji seksualnej przez wszystkie stopnie tego wyzwolenia; wyzwolenia w stosunku do powinności, do których heteroseksualność jest jeszcze w naturalny sposób przywiązana i aż do samotnego upajania się narkotykami, gdyż już nie trzeba żadnej więzi międzyludzkiej, gdyż wreszcie rozpadają się więzi odpowiedzialności [...]. Wszystko jest dozwolone, nic nie jest absolutnie zakazane. Nic być może, nie jest już zakazane w stosunku do drugiego człowieka (TW, s. 305-306).

Absolutyzacja wolności czyniąca z wolności miarę wszystkich wartości prowadzi do zerwania więzi między wolnością a światem wartości - etyki i prawa, a w konsekwencji do negacji heteronomicznej powinności, zaniku odpowiedzialności, atrofii więzi społecznych, niemożności „rozróżnienia dobra i zła”; wszystko to prowadzi, w przekonaniu Levinasa, do zachwiania duchowych podstaw Zachodu, opartych na równowadze wolności i wartości ${ }^{4}$.

W przeciwieństwie do totalitarnego wymiaru historii Tego-samego rozpuszczającego jednostkowość człowieka w uniwersalności historii, w jej wymiarze indywidualistycznym popędowa rewindykacja wolności prowadzi do wyrugowania z istnienia ludzkiego wszelkich treści uniwersalnych na rzecz ,gry wpływów i popędów [...] bez podmiotu” (BNM, s. 106). Tak jak historia uniwersalna znajduje swój kres w przywołującej istnienie przedludzkie anonimowej immanencji, tak istnienie popędowe aktualizuje założone w strukturze bytu ludzkiego jako ontologiczna możliwość istnienie zmysłowe. W historii Tego-samego człowiek, wychodząc od swej wolności, poświadczającej separację od bytu, urzeczywistnia zatem jedną z dwóch kontradyktorycznych na jej gruncie możliwości: zasadę swojego istnienia czerpie albo z usuwającej jednostkowość bezosobowej immanencji historii empirycznej, albo z nieredukowalnej do uniwersalności historii jednostkowości.

${ }^{4}$ „Kiedy okazuje się, że szczęście człowieka i wolność człowieka wymagają zniesienia prawa, kiedy wszelkie prawo okazuje się prawem represyjnym, kiedy wolność pojmuje się jako samowolę, wtedy Zachód objawi się sobie samemu jako zaprzeczenie tego wszystkiego, czym był dotąd, jako zerwanie z tym, czym był według Biblii i według wartości humanistycznych analogicznych z Biblią" (TW, s. 306). 
Wyrażający się we współczesności kryzys historii Tego-samego jawi się w ten sposób Levinasowi jako kryzys samego człowieka, esencjalna niemożność utrzymania osobowej integralności określonej z jednej strony przez radykalną niepowtarzalność, a z drugiej przez zapośredniczające wewnątrzwspólnotową komunikację, wiążące wszystkich uczestnictwo w porządku sensu uniwersalnego.

W przekonaniu Levinasa również artykułującej dyskursywnie To-samo myśli filozoficznej nie udało się ugruntować tej łączącej jednostkowość i uniwersalność osobowej esencji człowieka: w jej dziejach przeciwstawiają się sobie dychotomicznie wychodząca od jednostki orientacja monadyczno-indywidualistyczna (np. egzystencjalizm) oraz wychodząca od całości bytu orientacja totalistyczna (racjonalistyczna metafizyka, historyzm, socjologizm, naturalizm).

W potwierdzonym przez bankructwo historii Tego-samego kresie człowieka jako jej zasady Levinas widzi kres pewnej rewindykowanej przez filozofię od samego jej zarania formy człowieka, a mianowicie człowieka jako podmiotu rozumnego i wolnego, kształtującego siebie i swój stosunek do świata wedle wymogów racjonalności poznawczej. Jeśli we wcześniejszej fazie racjonalistycznej metafizyki podmiot odnajdował miarę swej rozumności w poddaniu się usensawniającym jego byt transcendentnym wymogom logiczno-intelligibilnej struktury bytu, to od czasów nowożytnych - Levinas idzie tu śladem Heideggerowskiej krytyki metafizyki podmiotowości - odnajduje ją w swej tożsamości, stając się fundamentem i celem rzeczywistości, tzn. źródłem jej sensu i wartości. W kryzysie historii, stymulujących ją emancypacyjnych projektów, Levinas dostrzega kryzys zachodniego, rewindykującego racjonalny podmiot antropocentrycznego humanizmu, w którym ,jeszcze do stosunkowo niedawnych czasów ludzie Zachodu szukali swej racji bytu", a w którym wyraża się ,uznanie niezmiennej esencji zwanej człowiekiem, uznanie jej centralnego miejsca w ekonomii Rzeczywistości oraz jego wartości dającej początek wszelkim wartościom" (TW, s. 297). W planie historii filozofii kryzys humanizmu ${ }^{5}$ oznacza wyczerpanie się wyrażającej ten

5 Z uznaniem podmiotu za źródło wartości wiąże się, zdaniem Levinasa: (1) uznanie rzeczywistości historycznej za źródłową sferę przejawiania się i realizacji wartości, a w konsekwencji: (2) uznanie, że miarą wartości i ideałów jest możliwość ich urzeczywistnienia i że u podstaw tego utożsamienia rzeczywistości i rozumności leży czas 
antropocentryczny idealizm filozofii świadomości (,dziś jeszcze powiadam, że Auschwitz jest dziełem cywilizacji idealizmu transcendentalnego", QEW, s. 84).

Historia jawi się zatem jako ostateczny argument w Levinasowskiej krytyce racjonalnego, określającego się przez poznawczą tożsamość podmiotu. Przez dialektykę oświecenia ukazuje ona bowiem, nie tylko de facto, ale właśnie de iure, filozoficzną nieprawomocność leżącego u podstaw antropocentrycznego humanizmu podmiotu refleksyjnego, który usiłuje rozpoznać się - tj. osiagnąć refleksyjną tożsamość w alienujących go historycznych formach jego uprzedmiotowienia: „,bezsens ogromnych przedsięwzięć $[\ldots]$ poucza o kruchości człowieka [...], świadomości siebie”; „doświadczenie ludzkiej nieskuteczności”, „odwrócenie wszelkich rozumnych projektów” - wszystkie te „sprzeczności [...] rozrywają świat rozumny pochodzący rzekomo z racjonalnego prawodawstwa [...], rujnują identyczność tego, co podmiotowe" jako ,identyczność par excellence, do której sięgała wszelka identyczność tego, co identyczne" (HAH, s. 67, 87).

Ta widzialna w świecie historii ruina podmiotu racjonalnego stanowi zasadniczo o kryzysie racjonalistycznego projektu świata, na mocy którego rozum - przez swoją pojęciową ogólność - znosi wszelką odmienność, redukując ją do przedstawienia i wpisując w immanencję własnej tożsamości. W tej racjonalistycznej formule sensu, wedle której poznawcza racjonalność stanowi miarę wszelkiej racjonalności, Levinas upatruje ostateczny wyraz kryzysu człowieka i samego bytu: w historii współczesnej skupia się bowiem i odsłania całość antropogennej i sensogennej aktywności człowieka racjonalnego, a wraz z nią reprezentujący rzeczywistość zhumanizowany byt.

Ukazując kryzys historii, podmiotu, sensu bytu, wskazując jego organizujące się wokół kategorii tożsamości, sensu racjonalnego, wolności i autonomicznego podmiotu źródła, Levinas podtrzymuje postnietzsche-

ekonomiczny - określony i przewidywalny - jako czasowy wymiar urzeczywistniania wartości oraz (3) afirmacja przemocy jako naturalnego środka realizacji urzeczywistnianych w historii wartości. Stąd też, wedle Levinasa, pokój wyrosły z historycznej realizacji wartości jest zawsze pokojem zwycięzców, wyrosłym zatem z przemocy: „pomimo całej swej wspaniałomyślności zachodni humanizm nigdy nie umiał wątpić w zwycięstwo, nigdy nie umiał zrozumieć porażek, ani przemyśleć historii, której zwyciężeni mogliby użyczyć jakiegoś istotnego sensu” (TW, s. 302). 
ańską krytykę racjonalistycznej kultury Zachodu, nie podejmuje wszakże jej nihilistycznych konsekwencji ujawnianych przez współczesny antyhumanizm: nie utożsamia bowiem kryzysu racjonalności poznawczej z kresem sensu i rozumności w ogóle, kryzysu zośrodkowanego wokół tożsamości podmiotu z kresem podmiotowości ludzkiej, lecz usiłuje radykalnie przeformułować rozumienie sensu, podmiotu, rozumności.

Czyni to, zakorzeniając owe kategorie w poprzedzającej wszelkie zaangażowanie w bycie - poznanie, praca, wspólnota, historia - metafizycznej etyczności, którą otwiera bezwarunkowa odpowiedzialność za Drugiego. Właśnie to transcendentne, niezmediatyzowane świadomością i praca, a zatem wolne od przemocy, etyczne napotkanie Drugiego w jego etycznej odmienności uwalnia - w przekonaniu Levinasa - egocentryczne i egologiczne ja od przymusu identyfikacji, monadycznego zamknięcia, depersonalizującego uczestnictwa w historii. Stanowiąc pierwotny, niewywiedliwy z transcendentalnej legislacji podmiotu sens, odpowiedzialność - jako pierwotny fakt istnienia ludzkiego - umożliwia relację z Drugim, a wraz z nią otwiera osobowy wymiar bytu ludzkiego: z jednej strony umożliwia doświadczenie tego, co Inne, a z drugiej jednostkowość i niepowtarzalność jednostki: związana z pozwaniem do odpowiedzialności wina, z racji swej an-archicznej niezbywalności, jest zawsze „moją” winą. Ów imperatywny sens odpowiedzialność i wina czerpią z transcendentnego źródła: w nieodwracalnej relacji odpowiedzialności z Drugim i tylko w niej przejawia się transcendentny Bóg jako pozostawiający swój ślad jedynie w niepamiętnym pozwaniu do odpowiedzialności deus absconditus.

Wyrywając ,bytowania spod jurysdykcji historii i przyszłości”, metafizyczno-etyczna prawda jednostki urzeczywistnia się zatem we wzniesionej ponad widzialną historią relacji z Drugim-Bliźnim, w radykalnie zsubiektywizowanym, niekomunikowalnym przeżyciu odpowiedzialności i winy, w przekraczającej sferę bytu wewnętrzności jednostki. W ten sposób obiektywizującemu byt człowieka osądowi historii Levinas przeciwstawia niewidzialny, rewindykujący subiektywność jednostki i nadający jej istnieniu sens absolutny osąd etyczny, zakładającemu tożsamy i jednolity podmiot teologicznemu finalizmowi historii absolutny wymiar etycznej teraźniejszości. Jeśli w odwołującym się do obiektywnego porządku historii anonimowym osądzie historii liczy się tylko ,sens ostateczny” (TI, s. IX), to osąd etyczny ,przywraca każdej chwili jej pełne 
znaczenie": niezbywalne pozwanie do absolutnej odpowiedzialności wymaga, by każdy, w każdej chwili swego istnienia, ,był w pełni obecny w swym wyborze" (TW, s. 87), by znał ostateczny sens swego istnienia. Jeśli zwieńczający i przynoszący spełnienie moralne osąd historii zakłada kres czasu historycznego, to absolutna, niedająca się zatem nigdy urzeczywistnić w jednorazowych aktach moralnych, odpowiedzialność „wymaga jako swego ostatecznego warunku [...] czasu nieskończonego": ,spełnienie moralne jest niemoralne [...], jest absurdalne, tak jak unieruchomienie czasu, którego wymaga" (TW, s. 86).

W ten sposób Levinas przeciwstawia etykę, jako skrajnie zindywidualizowaną i uetycznioną eschatologię historii, nieskończony czas chwil absolutnych, czasowi teleologicznemu, subiektywne przeżycie etyczne - doświadczeniu obiektywnemu. Tym samym jednak restytuowałby nieprzekraczalny dualizm zjawiska i bytu samego w sobie, istnienia nieautentycznego $\mathrm{i}$ istnienia autentycznego, stając przed wieloma trudnościami.

Przed Levinasem staje pytanie, czy radykalna, strącająca historię w sferę zjawiskową subiektywizacja osądu moralnego nie zaprzecza ,uniwersalności Boga"-Dobra i czy tym samym nie grozi ona popadnięciem w - niosący ze sobą zgodę na zło - manichejski dualizm istnienia angelicznego i złego bytu-historii, która ,pozostawiona swemu fatalizmowi [...] mnoży zbrodnie”: „człowiek wewnętrzny byłby wystarczający, gdyby nie cierpieli niewinni [...]. Taka sprzeczność, jak cierpienie niewinnych, nie zostaje przezwyciężona w wewnętrznej miłości. Także tutaj wewnętrzność nie jest równoznaczna z uniwersalnością" (TW, s. 148). W imię etycznej uniwersalności, ,życie wewnętrzne nie może zrezygnować z wszelkiej widzialności" (TI, s. 225) - historia wymaga humanizacji i moralizacji. Należy pogodzić transcendentny wobec historii osąd moralny z historią samą, doprowadzić do ,zbieżności między moralnością a rzeczywistością” (TI, s. 283), tak jednak, aby historia nie „rozwijała etyki, lecz ją rozszerzała" (QLT, s. 100).

Broniąc etycznej uniwersalności Absolutu i wystrzegając się sprowadzenia moralności do sfery ,subiektywnych mniemań i iluzji”, Levinas staje przed koniecznością ugruntowania przejścia od porządku transcendentnej etyczności do porządku bytu i historii; musi zatem - skoro etyczności przysługuje przywilej metafizycznej pierwotności - wywieść historię z etyki, jak również wyjaśnić możliwość alienacji historii. Toteż 
w perspektywie etycznej transcendencji musi zapytać o możliwość wyjścia poza porządek istnienia naturalnego i zmysłowego, zatem o możliwość przejścia od podmiotu egoistycznego do wykraczającego poza egocentryczną spontaniczność i zawłaszczanego przez alienacyjny ruch historii istnienia uniwersalnego w świecie obiektywnym, a tym samym o możliwości wspólnoty i obiektywno-racjonalnej komunikacji: w jaki sposób zamknięte w swej egoistycznej spontaniczności i tożsamości, traktujące się jako siły naturalne, indywidua mogą wejść we wzajemne relacje, by następnie, zawieszając tę naturalno-popędową wolność, ukonstytuować język racjonalny i komunikowane przezeń znaczenia obiektywne ${ }^{6}$ oraz poddać się uniwersalnemu otwierającemu porządek historii - prawu państwa. Jeśli naturalistyczny indywidualizm nie jest w stanie wyjaśnić zerwania monadycznego egoizmu, to z kolei racjonalizm nie potrafi pokazać, w jaki sposób autonomiczne w swej określonej wyłącznie przez wymogi poznawcze świadomości chcą i mogą ukonstytuować komunikację, nie tracąc zarazem swej jednostkowości: podzielając i wymieniając te same myśli i idee, same stając się uniwersalizującym ich istnienie przedmiotem (esencją człowieka), przekształcają się w abstrakcyjny moment jednego i tego samego, komunikującego się ze sobą samym - poprzedzającego komunikację i czyniącego ją pozorną - monadycznego rozumu. Wszystkie te pytania i problemy organizują się wokół kluczowej dla autora Totalité... kwestii pogodzenia - konstytuujących osobową esencję człowieka - jednostkowości i uniwersalności jego istnienia.

Taką zasadę, pozwalającą zuniwersalizować etykę przez ugruntowanie w niej porządku historii, a zatem zapośredniczyć przejście od opartej na odpowiedzialności transcendentnej wobec historii relacji etycznej z Drugim do otwierającej obiektywno-wspólnotowy wymiar istnienia ludzkiego relacji z Trzecim, Levinas wyprowadza z samej dynamiki

${ }^{6}$ Levinas przeciwstawia się tu zarówno naturalizmowi oraz pragmatyzmowi, jak i racjonalizmowi. Tak jak pragmatyzm i naturalizm, czyniący ze świadomości ,przypadek graniczny zaangażowania się w rzeczywistość” (,rezyduum celowości praktycznej”), nie są w stanie wyjaśnić przejścia ze sfery stymulowanej życiem popędowym aktywności naturalnej do podporządkowującej świat racjonalności praktyczno-instrumentalnej, a następnie do zawieszającej aktywność naturalno-praktyczną racjonalności obiektywno-poznawczej, tak z kolei klasyczny racjonalizm, wedle którego, by żyć, „chcieć, należy uprzednio przedstawić sobie to, czego chce się [...], swój cel” (TI, s. 143), nie jest w stanie wyprowadzić z ,nieczułego przedstawienia” „troski o życie”. 
istnienia etycznego. Zasadę tę, zasygnalizowaną jedynie w Totalité..., a rozwiniętą w Autrement, Levinas odnajduje w stanowiącej sam wymóg odpowiedzialności sprawiedliwości jako odpowiedzialności rozszerzonej na innych Drugich, czyli podzielonej - proporcjonalnej: odnosząc się zarówno do Drugiego, jak i do Trzeciego, podmiotowość etyczna musi dysponować zewnętrzną, uniwersalizującą odpowiedzialność, ogólną miarą pozwalającą osądzić, „który spośród nich jest ważniejszy, czy jeden nie jest prześladowcą drugiego" (ENE, s. 121). Zamkniętą intersubiektywność Ja-Ty, opartą na asymetrycznej i nieodwracalnej relacji, zastępuje zatem intersubiektywność powszechna, zapośredniczona prawem uniwersalnym, czyli oparta na symetrii i wzajemności (praw i obowiązków, równości wobec prawa). W ten sposób sprawiedliwość „wymaga instytucji postępowania sądowego [...], są to być może same narodziny $[\ldots]$ porządku społecznego, [...] narodziny instytucji państwa, jego koniecznej władzy dla samej instytucji odpowiedzialności [...]" (QEV, s. 97). Właśnie jako instancja uniwersalizacji etyki sprawiedliwość jest „etycznym wymogiem logiki i prawdy” (AQS, s. 61), leży zatem u podstaw świadomości i obiektywności. Nadając uniwersalne znaczenie etycznym - zrodzonym w stanowiącym odpowiedź na pozwanie do odpowiedzialności etycznym geście materialnego „ofiarowania świata Drugiemu" - znaczeniom rzeczy, umożliwia ona bowiem znakową konstytucję języka, mediatyzuje przejście od motywującego „chęć mówienia” bezsłownego języka etycznego do języka racjonalno-obiektywnego, w którym i poprzez który jedynie odsłania się właśnie intelligibilno-obiektywny porządek świata. W ten sposób zakorzeniona w sprawiedliwości etyczna idealność sensu warunkuje przejście od danego w porządku naturalnym znaczenia relatywnego i subiektywnego rzeczy do poznawczej idealności ich znaczenia powszechno-obiektywnego, od ja zmysłowego i egoistycznego do ja uczestniczącego w uniwersalno-obiektywnym porządku świata.

Uniwersalizująca związany z odpowiedzialnością sens absolutny i ucieleśniona w sprawiedliwości uniwersalność sensu ma zatem walor etyczny, nie zaś poznawczo-racjonalny, urzeczywistnia się pierwotnie w życiu wspólnoty, a nie w intelligibilnej strukturze bytu obiektywnego. Porządek tego, co osobowe konstytuuje się właśnie jako synteza niepowtarzalności jednostki (odpowiedzialności) i uniwersalności jej sensu (sprawiedliwości). 
Na tej dynamice przejścia od odpowiedzialności do sprawiedliwości Levinas funduje ideę fenomenologiczno-etycznego creatio continua świata, którą przeciwstawia leżącej u podstaw tradycyjnej metafizyki idei kreacji ontologiczno-kosmologicznej, ujmującej Boga i świat w znoszących transcendencję Boga kategoriach bytu obiektywnego: wychodząc od płynącego z ,niepamiętnej przeszłości” i wiążącego jednostki pierwotnego sensu, konstytuują one wspólnotę, a wraz z nią rozjaśniającą mrok istnienia anonimowego etyczna, a następnie obiektywną, intelligibilność bytu.

Totalizująca jego doświadczenie historia jawi się zatem jako spełnienie kreacji świata, będące zarazem aktem kosmologicznej - odrywającej człowieka i świat od ich transcendentnej genezy - alienacji aktu stwórczego - oto ostateczna racja, dla której Levinas nadaje współczesności apokaliptyczny sens. Zło historii polega właśnie na postępującej obiektywizacji i autonomizacji sprawiedliwości, a zatem na oderwaniu jej od etycznych korzeni, czyli od odpowiedzialności. Alienacja sprawiedliwości wyrażałaby się w nadaniu uniwersalnej wartości abstrakcyjno-racjonalnemu prawu i egzekwującym go instytucjom prawno-politycznym, które mediatyzowałyby wszelkie więzi ludzkie, znosząc bezpośrednią więź jednostkowej, nieuwarunkowanej odpowiedzialności: „istnieją okrucieństwa, które są straszne, gdyż pochodzą z wymogów porządku rozumowego" (TH, s. 102).

Tej wyalienowanej, realizującej wartości etyczne środkami historii, rodzącej przemoc sprawiedliwości abstrakcyjnej Levinas przeciwstawia sprawiedliwość równoważoną przez odpowiedzialność (miłosierdzie), która, będąc ,przed sprawiedliwością, jest po” niej, by minimalizować opresywny charakter prawa poprzez równowagę między abstrakcyjną normą stosującą do wszystkich jedną miarę a niepowtarzalną sytuacją jednostki jako ,przypadku jednostkowego” (,sprawiedliwość bez kata”). Wyrastającemu z „ograniczenia wojny między ludźmi” państwu, w którym uniwersalność jest tożsama z ,powrotem tego, co wielorakie do jedności” (PP, s. 339), Levinas przeciwstawia państwo pochodzące z „ograniczenia miłosierdzia” wobec Drugiego w obliczu Trzeciego. Ideał tego państwa Levinas łączy z demokratycznym porządkiem Zachodu; „państwo liberalne” nie jest jednak związaną z państwem wojny „kategorią empiryczną, lecz ,etyczna, która pozostawionemu wobec ogólności prawa człowiekowi pozwoli zachować sens swej odpowiedzialności” (QS, s. 62). 
W opisanej konstrukcji uderza niewątpliwie dysproporcja między diagnozą historii realnej jako kulminującego we współczesności hiperbolicznego zła a remedium w postaci postulatu minimalizacji - wpisanej w zobiektywizowaną sprawiedliwość - przemocy, a zatem minimalizacji naturalnej, tworzącej samą tkankę historii alienacji sprawiedliwości. Dysproporcja ta ma swoje źródło w rozrywających koherencję dyskursu Levinasa jego immanentnych trudnościach i pęknięciach.

\section{Konkluzje krytyczne}

Wiążąc odpowiedzialność ze sprawiedliwością, transcendentną relację z Drugim z bytem, Levinas zwraca się z jednej strony przeciwko rewindykującemu prawo bytu, ateizmowi i poganizmowi, a z drugiej przeciwko klasycznemu dualizmowi metafizycznemu, łączącemu spełnienie się człowieka ze światem ponadzmysłowym. Levinasowski człowiek sytuuje się ponad doczesnym porządkiem bytu i historii, a jednak, wznosząc się ponad nim, spełnia się jedynie w nim, poddając go wymogom etycznego uniwersalizmu. Levinas usiłuje zatem uzgodnić - nie znosząc ich odrębności w jedności panteistycznej - dwie perspektywy: doczesną i metafizyczna, porządek widzialny i niewidzialny, ziemski i ponadzmysłowy, i w ten sposób połączyć skończoność z nieskończonością, ciało z duszą, filozofię moralną z filozofią społeczną, wolność z odpowiedzialnością. Tę próbę etycznego zmediatyzowania perspektywy doczesnej i perspektywy metafizycznej gruntuje na próbie wyprowadzenia z jednego i tego samego wymogu moralno-metafizycznego porządku odpowiedzialności i porządku sprawiedliwości, odpowiedzialności bezwarunkowej za Drugiego i odpowiedzialności proporcjonalnej za wszystkich.

Wydaje się jednak, że obu tych wymogów nie da się uzgodnić. Co więcej, są one w wyraźnym ze sobą konflikcie. Otóż: albo ponoszę bezwarunkową odpowiedzialność za Drugiego, a wówczas w swej radykalnej odmienności i absolutnym znaczeniu reprezentuje on jedynie samego siebie, albo ponoszę odpowiedzialność za wszystkich, a wówczas Drugiego nie poznaję w jego absolutnej odmienności, lecz poznaję go w jego ogólności jako reprezentanta zawiązującej się wokół prawa sprawiedliwości wspólnoty. Tożsame ze sprawiedliwością znaczenie uniwersalne bytu zdaje się tracić, wbrew intencjom Levinasa, swój wyprowadzony z odpowiedzialności sens absolutny, jeśli zważyć, że sprawiedliwość, 
jako przeddyskursywne i preracjonalne, etyczne znaczenie uniwersalne, które winno fundować porządek poznania i świadomości obiektywnej, porządek ów zakłada. Sprawiedliwość jest już odpowiedzialnością zobiektywizowaną, gdyż zakładającą możliwość porównania Drugiego i Trzeciego, a zatem istnienie zewnętrznej miary owego porównania, czyli praw. Sprawiedliwość zostaje faktycznie zrelatywizowana do świadomości poznającej, stanowiącej - wedle Levinasa - wyraz monadycznej autonomii podmiotu tożsamego.

Konflikt między odpowiedzialnością a sprawiedliwością, uniemożliwiając przejście od porządku metafizycznego do porządku doczesnego, daje się sprowadzić do konfliktu między transcendencją a ,ateistycznym" byciem-w-świecie, wiedzą a moralnością odpowiedzialnością a wolnością; przenika całe dzieło Levinasa, udwuznaczniając wiele jego zasadniczych kategorii. Dotyczy to również samej kategorii sprawiedliwości.

Otóż niekiedy Levinas skłonny jest wiązać sprawiedliwość z porządkiem bytu, a ten $z$ istnieniem nieautentycznym i złem. Taki projekt można by znaleźć w Totalité..., jeśli wziąć pod uwagę dwuznaczny status Tego-samego stanowiącego raz nieautentyczną modalność podmiotu, a raz samą strukturę jego odseparowania od bytu, warunkującą i umożliwiającą jego wejście w relację transcendentną z Drugim. Wówczas w myśli Levinasa odtwarzałaby się zwalczana przezeń dualistyczna metafizyka przeciwstawiająca etyczną sferę rzeczy samych w sobie sferze zjawiska (bytu). Istnienie autentyczne spełniałoby się poza byciem-w-świecie - poza historią i rzeczywistością - w subiektywnym, prerefleksyjnym przeżyciu moralnym odpowiedzialności za Drugiego, czyli w sferze jednostkowego, niepodlegającego obiektywizacji, uwewnętrznionego osądu moralnego - sumienia. Związane ze sprawiedliwością świadomość, poznanie i wiedza wyrażałyby znoszącą odmienność Drugiego autonomię podmiotu, Levinas mógłby wówczas poddać radykalnej krytyce całą racjonalistyczną tradycję filozofii, nie mogąc jednak usprawiedliwić własnego dyskursu. W tej optyce Levinas nie mógłby wyjaśnić, w jaki sposób konstytuujący się przez zapomnienie transcendencji podmiot monadyczny i egoistyczny jest w stanie otworzyć się na etyczną odmienność Drugiego; co więcej, nie jest wówczas w stanie ugruntować transcendencji jako postawy świadomie podjętej, a przecież taką możliwość powinien ugruntować, jeśli w odpowiedzialności chce widzieć zakładające aktywne oddziaływanie na ruch historii antidotum na jej postępujący nihilizm. 
Levinas usiłuje niewątpliwie ściśle związać odpowiedzialność i sprawiedliwość. Wówczas istnienie nieautentyczne nie wiązałoby się w sposób konieczny z historia, wolnością i poznaniem, lecz z ich modalnością nieautentyczną, czyli ze sprawiedliwością wyalienowaną. W tej optyce Levinas z kolei nie jest $\mathrm{w}$ stanie wyjaśnić, w jaki sposób wyrastająca bezpośrednio z odpowiedzialności sprawiedliwość może ulec wyobcowaniu, stając się zasadą zła. Levinas mówi o presji zalążkowego egoizmu oraz zawłaszczającego to, co ludzkie bytu anonimowego (po heideggerowsku ujętej „Istoty”) na podmiot, lecz wówczas jej skuteczność świadczyłaby o równorzędnym, niemal manichejskim statusie dwóch przeciwstawnych sobie zasad: istnienia etycznego i bytu, Dobra i Zła. Jeśli zatem w pierwszej perspektywie (Totalité...) Levinas nie jest w stanie jednoznacznie ukazać możliwości przejścia do istnienia autentycznego, tak w drugiej (Autrement...) nie może tego uczynić w odniesieniu do istnienia nieautentycznego, czyli pokazać, w jaki sposób podmiot - którego zasadę konstytucji stanowi odkryta w sobie, poprzez ślad pozwania, a nie w twarzy Drugiego, odpowiedzialność - może przekształcić się - jeśli nie przez sprawiedliwość, co jest tu wykluczone - w rewindykujący prawo bytu podmiot ontologiczny.

W tym ujęciu źródłem zła byłaby konieczna i permanentna alienacja sprawiedliwości, a nie sama sprawiedliwość i stymulowana przez nią obiektywność (można zapytać, czy konieczność alienacji nie znosi zła jako zła bądź, czy nie czyni walki z nim czymś bezowocnym i jałowym). Toteż nie przeciwstawiając radykalnie etyki i wiedzy, Levinas mówi - a wówczas usprawiedliwia własny dyskurs - o konieczności filozoficznej tematyzacji etycznego Mówienia zdradzającego się nieuchronnie w (obiektywnym) Wypowiedzianym, wycofującego się zeń. Tym samym Levinas nie może już w sposób radykalny poddać krytyce teoretycznej struktury tradycyjnej filozofii.

W tej perspektywie istnienie autentyczne wiązałoby się ściśle ze sprawiedliwością, a zatem z obiektywną sferą istnienia człowieka, z jego istnieniem wspólnotowym. Jeśli zatem na gruncie pierwszej perspektywy mielibyśmy do czynienia z maksymalistycznym projektem rewolucji etycznej (bezwarunkowa odpowiedzialność, absolutna wina, ekspiacja) przeciwstawionej rewolucji historycznej, to na gruncie drugiej z projektem minimalistycznym, związanym z rzeczywistością zastaną (państwo liberalne), sprowadzającym się do etycznej - odwołującej się do odpo- 
wiedzialności - melioryzacji nigdy nie dość doskonałej sprawiedliwości prawno-politycznej.

Levinas nie jest w stanie uzgodnić odpowiedzialności i sprawiedliwości. Tym samym załamuje się zasadniczy dla jego filozofii projekt ugruntowania osobowej esencji człowieka, integrującej w niepodzielnym akcie istnienia jego jednostkowość z uniwersalnością wiążącego go sensu, a wraz z tym projektem ożywiająca cały dyskurs Levinasa nadzieja na transhistoryczne wyjście poza apokaliptyczny horyzont ,nieludzkich wydarzeń historii”.

\section{Oznaczenia cytowanych w tekście dzieł Levinasa}

AM - L'Actualité de Maimonide, [w:] Cahier de l'Herne, Emmanuel Levinas, Paris 1992.

AQS - Autrement que savoir, Paris 1987.

BNM - O Bogu, który nawiedza myśl.

DE - De l'évasion, „Recherches Philosophiques” 1935-1936, no 5.

ENE - Entre nous. Essais sur le penser-à-l'autre, Paris 1991.

HAH - Humanisme de l'autre homme, Montpellier 1972.

NP - Noms propres, Montpellier 1976.

PP - Paix et proximité, „Les Cahiers de La nuit surveilleé” 1984, no 3.

QEV - François Poirié. Emmanuel Levinas, „Qui êtes vour”, Lyon 1987.

QLT - Quatre lectures talmudiques, Paris 1968.

QRPH - Quelques réflexions sur philosophie de l'hitlerisme, [w:] Cahier de l'Herne, Emmanuel Levinas, Paris 1992.

TA - Transcendence et hauteur, „Bulletin de la Société francaise de philosophie" 1962, no 3.

TI - Totalité et Infini. Essais sur l'exteriorité, La Haye 1961.

TW - Trudna wolność, Gdynia 1991. 